\title{
On the Irregular Moult in the Algerian Mouse, Mus spretus Lataste, 1883
}

\author{
L. Javier PALOMO \& J. Mario VARGAS
}

\begin{abstract}
Palomo L. J. \& Vargas J. M., 1988: On the irregular moult in the Algerian mouse, Mus spretus Lataste, 1883. Acta theriol., 33, 6: 67-86 [With 2 Tables \& 5 Figs.]

On the basis of 1516 specimens obtained between March 1982 and February 1986 the irregular moults in Mus spretus were analyzed propounding individual and group models in relation to deterministic genetic environmental binomial. There were individuals in irregular moult throughout the year with two periods in which the rates were a little higher than the yearly mean: March-May and October-December. Also, in the last period, there was an increase in the rate of moulting. All these factors show a certain influence on the control of the moult, but the topographic divergences, the lack of a consistent time pattern of moulting among the specimens dyed in the laboratory, as well as the existance of a high percentage of animals that do not moult within the above-mentioned period or these that moult out of this time period, and the existance of wide areas of coat with no alterations, recommend the rejection of the idea of a seasonal moult in its stricter sense. Moreover, data on the symmetrical pattern in the distribution of moulting areas, and the diffused moult or "Kritzelhaarung" are analyzed.

[Dept. Zoology, Fac. Sciences, Univ. Málaga, Apdo 59 - 29080 Málaga, Spain].
\end{abstract}

\section{INTRODUCTION}

The first two postnatal moults which Mus spretus undergoes are complete and show a regular topography. Such moults are called juvenile and intermediate respectively and they occur, within margins of variability, during a certain period of time after birth (España et al., 1985). Once the third coat is acquired, the animals undergo new moulting processes whose temporary and topographic manifestations obey an irregular pattern. The pattern so far described is comparable to other species of murids: Rattus rattus (Sans-Coma et al., 1987), Apodemus sylvaticus (Fullagar, 1967; Schmidt, 1970; Sans-Coma et al., in press), and Mus musculus (Dry, 1926; López-Fuster, 1978).

The irregular moults of Mus spretus affect, in some cases, the whole coat and in others, restricted areas. In both instances, they follow one another in a more or less continuous way throughout the life of the animals, being seemingly independent of season, age or physiological condition (España et al., 1985). However, such processes of irregular moults, described in other species of rodents, have been related to 
periodic seasonal variations (Sealander, 1951; Stein, 1960; Khateeb \& Johnson, 1971).

In the present paper the irregular moults after the third coating in Mus spretus are analyzed, propounding individual and group models in relation to deterministic genetic-environmental binomial.

\section{MATERIAL AND METHODS}

Analyzed material. 1516 specimens $(870 \hat{0} \hat{o}, 646+q)$ were studied. They were obtained between March 1982 and February 1986, in the sugar cane plantations (Saccharum officinarum L.) at the molith of the Guadalhorce River, in the province of Málaga (Spain) (UTM: 30 S UF65 and UF66). The monthly distribution of the above-mentioned captures was the following: January: $116 \delta \hat{\delta}, 92$ 우;

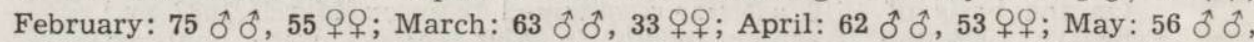

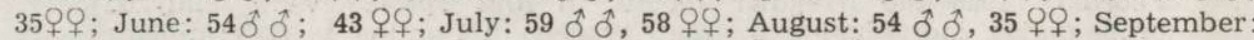

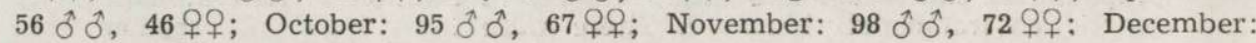
82 ô $\widehat{\partial}, 57$ 우우.

In the same way, two litters, born in the laboratory, were analyzed: 20.07 .85 $(n=3)$ and 25.08.85 $(n=1)$, whose specimens were held captive for $214,330,343$ and 309 days, respectively.

Evaluation of the moulting processes. The moulting of the sectioned animals was observed throughout the analysis of the pigmentation patterns of inner surface of the skin (Becker, 1952). The development of moulting in living specimens was followed by staining the coat with a black dye, which easily contrasted with the original coloration, according to the technique described by Johnson (1958).

Evaluation of the relative age. The relative age of the captured specimens was determined on the basis of the different coats the animals acquire, its moulting patterns and the images of the upper molar wear. Eight classes of relative age
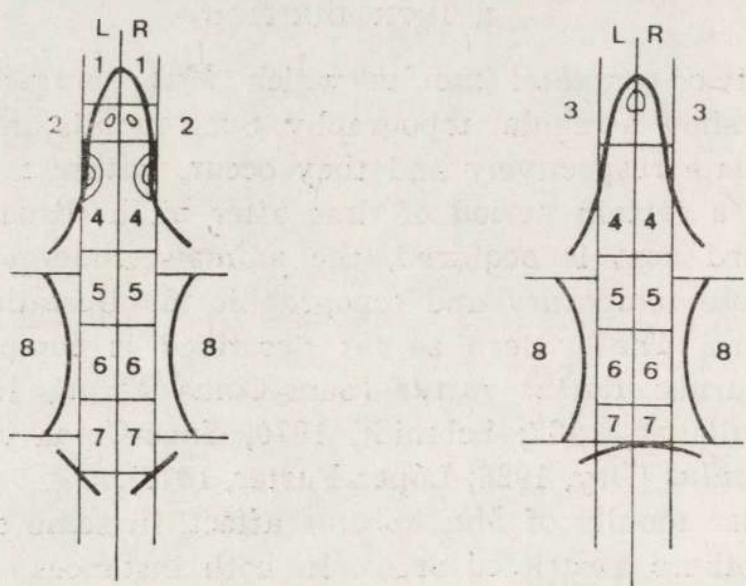

Fig. 1. Dorsal and ventral areas established in the inner surface of Mus spretus according to Schaible (1969). Each one is divided into symmetrical halves: left (L) and right (R). 1: Nasal; 2: Temporal; 3: Nasotemporal; 4: Aural; 5: Costal; 6: Lumbar; 7: Sacral; 8: Flank. 
were established: A-H (España et al., 1985). The last four classes $(\mathrm{E}-\mathrm{H})$ correspond to specimens which had already acquired the third coat and were liable to undergo processes of irregular moult.

Obtaining the moulting rates. In order to study the irregular moult, the extension of the inner surface was divided into a number of areas that cover all of it. A total of seven dorsal areas and six ventral ones were established, and were divided into two symmetrical halves (left and right). The proposed areas are shown in Fig. 1.

The established moulting rates are relative values that aim to state numerically the stage of moulting of any animal or a group of specimens.

The zonal moulting rate (ZMR) was obtained from the size of melanin accumulation detected in each one of the established areas, according to the following scale:

0 : lack of moulting,

1: less than $50 \%$ of examined area with melanin accumulation,

2: more than $50 \%$ of examined area with melanin accumulation.

The dorsal moulting rates (DMR), the ventral (VMR) and the total ones (TMR) were obtained by dividing the total of the respective ZMR among the number of areas considered in each case and calculated according to the equations:

$$
\mathrm{DMR}=\frac{\Sigma \mathrm{ZMR}}{14} ; \quad \mathrm{VMR}=\frac{\Sigma \mathrm{ZMR}}{12} ; \quad \mathrm{TMR}=\frac{\Sigma \mathrm{ZMR}}{26} .
$$

Any of the so-defined rates vary between 0 and 2, depending on the extension of coat which is affected by the moulting processes.

\section{RESULTS}

Among the analyzed specimens, 447 showed irregular moults. This represents $42.1 \%$ of all the animals that had already acquired the third coat $(n=1063)$. There were animals in moult throughout the year, although the highest percentages occurred during the last months of the year (Fig. 2). On the whole, there were two periods with many animals in moulting: March-May and October-December. Upon analyzing the distribution of the moult according to age classes, the percentage of moulting animals was found to be highest among the oldest ones, class E: $39.0 \%(n=423)$; class F: $43.2 \%(n=336)$; class G: $39.8 \%(n=181)$; class H: $53.1 \%(n=123)$.

The DMR were always higher than the VWR. A slight decrease of both rates, could be seen as the animals get older in the analyzed sample. This fall was much more evident in the ventral zone than on the back (Table 1). Throughout the year, the rates underwent similar fluctuations on the back and the underside (Fig. 3). The highest values corresponded to October-November and the lowest ones to a wide period, from January to May in the case of the DMR, and from January to July in the case of the VMR.

The increase of the above-mentioned moulting rates, in October and 


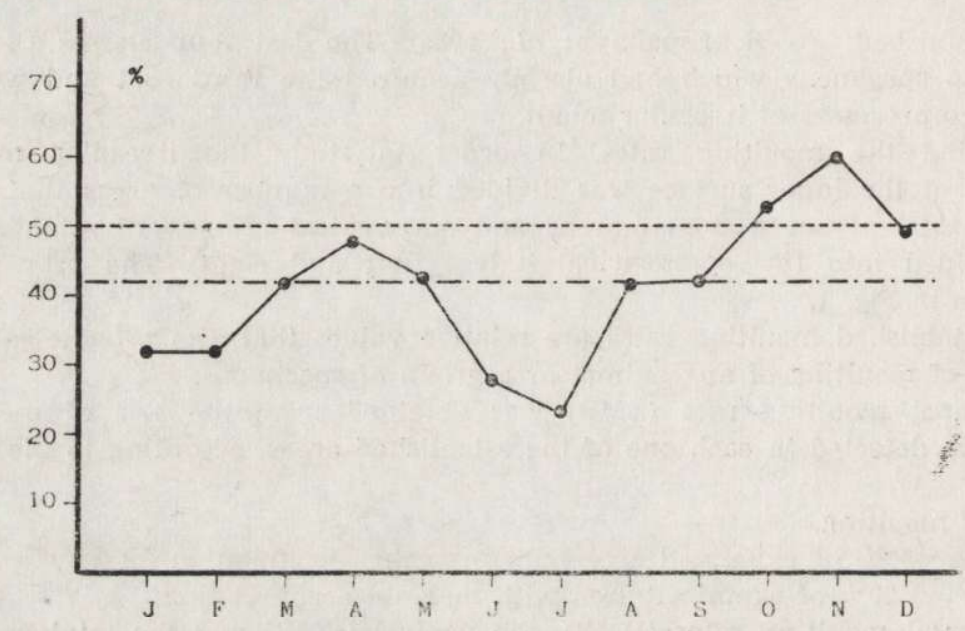

Fig. 2. Percentages of Mus spretus in irregular moults through the year. (- - ): $50 \% ;(-,-$,$) : annual average (42.1 \%)$.

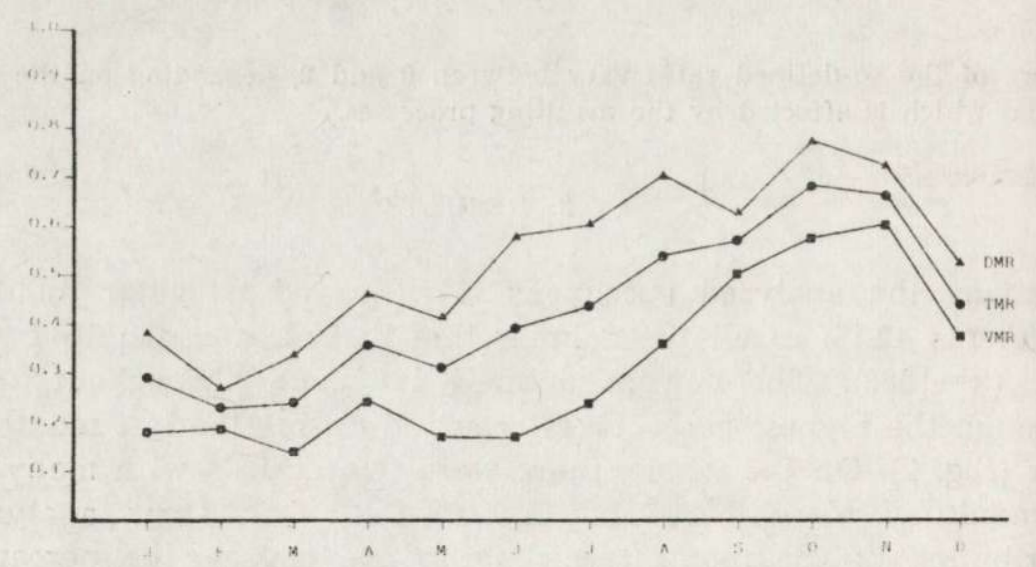

Fig. 3. Mus spretus from southern Spain. Dorsal moulting rates (DMR), ventral (VMR) and total ones (TMR) fluctuations through the year.

Table 1

Mus spretus from southern Spain. Dorsal moulting rates (DMR), ventral (VMR) and total ones (TMR) in relation to age classes established: $\mathrm{E}-\mathrm{H}$.

\begin{tabular}{lcccc}
\hline & E & F & G & H \\
\hline DMR & 0.59 & 0.51 & 0.54 & 0.52 \\
VMR & 0.44 & 0.34 & 0.28 & 0.23 \\
TMR & 0.52 & 0.43 & 0.42 & 0.39 \\
\hline
\end{tabular}


Ncvember, also coincided with the period in which the number of animals moulting was the highest (Fig. 2). In general, there was no correlation between the monthly TMR and the number of animals in moult $(r=0.52, p>0.1)$.

In spite of the fact that individual irregularity was evident in the distribution of the pigmentation patterns, the right and left ZMR of the sample analized on the back and on the underside were quite similar and symmetrical (Fig. 4). The differences were not significant $\left(\chi^{2}=6.63\right.$, $p<0.01$ ). However, the absolute values of the right and left ZMR tended to offer a greater disparity in the most adult age classes. Both on the back and the underside, the area with a higher moulting percentage was the aural one, followed by the sacral (dorsal) and by the flanks (ventral) areas.

In some specimens an irregular moult distinguished by the existence of a group of black melanin spots on the inner surface was detected. This type of moulting is called diffused moult or "Kritzelhaarung". In this case, $12.1 \%$ of the animals in irregular moulting showed what could be considered a diffused pattern, class E: $8.5 \%(n=165)$; class F: $14.7 \%$ $(n=145)$; class G: $11.1 \%(n=72)$; class H: $15.4 \%(n=65)$. Animals in
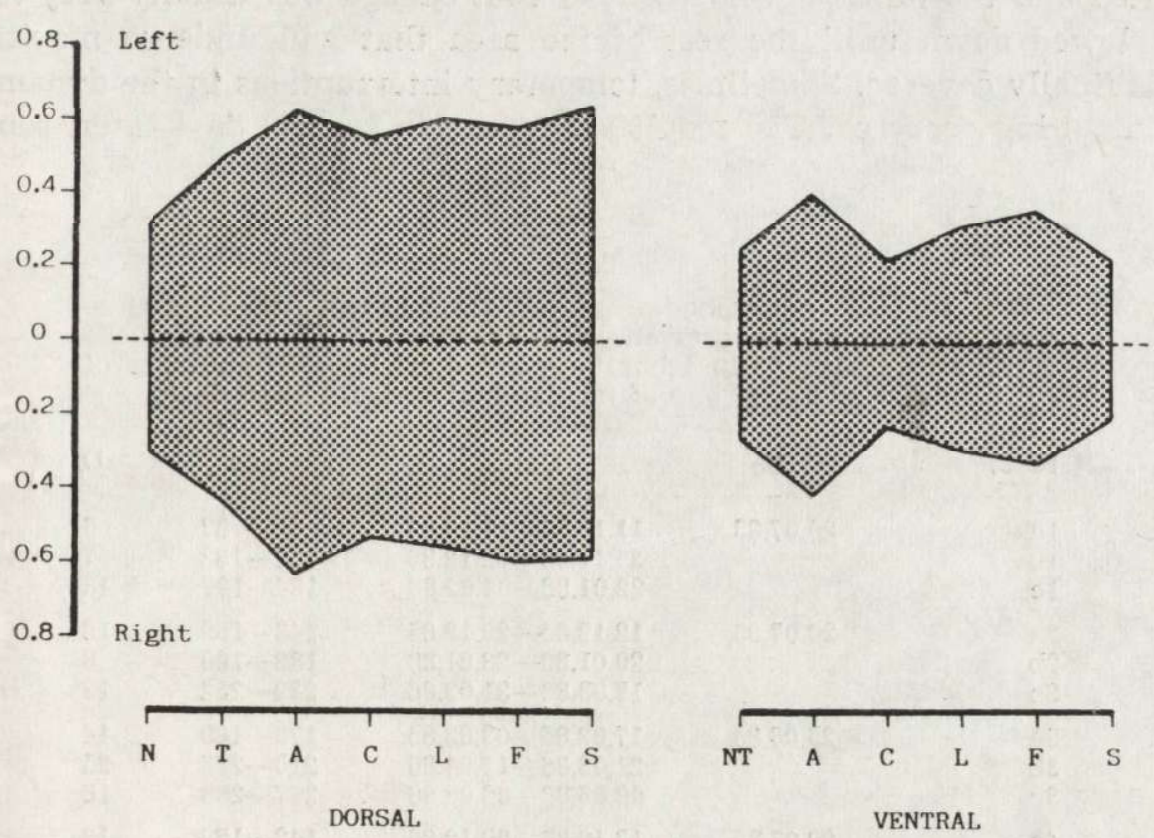

Fig. 4. Zonal moulting rates (ZMR) fluctuations in relation to left and right halves in different areas established (see Fig. 1). 
diffused moult could be found throughout the year, but the highest values were reached in January and February.

Working with slaughtered animals provides a precise, although a bit objectionable, image of moulting, without being able to determine exactly their number, duration and topographic extent. Animals born in the laboratory and dyed later were observed periodically making it possible to detiect, once the third coat was acquired, the development of $13 \mathrm{ir}-$ regular moults. The dates and ages corresponding to the development of each one of these moults, as well as their duration, are recorded in Table 2. As can be verified, moults were detected in all the months that were considered (October-June) and they were at very varied absolute ages, between 81 and 331 days. The duration of the moults likewise fluctuated between 6 and 25 days. The areas of coat moulting in each one of the irregular moults studied in captivity are represented in Figure 5. In some cases, the coat changes affected several identical zones consecutively ( $4 \mathrm{a}, 4 \mathrm{~b}$ and $4 \mathrm{c}$ ) while in others the successive moults seemed to complement each other in order to renew a wider extent of coat (1a and $1 \mathrm{~b}$ ). The exhaustive pursuit of the specimens during the moulting processes allows us to deduce their sequences and development. In general, the area(s) involved during the first stages of moulting were varied and the initial development of coat change was usually very fast. It slowed down until the rest of the area that will undergo moulting was finally covered. Sometimes, temporary interruptions in the dynamics of moulting occurred. The moult started again several days later, some-

Table 2

Dates and ages corresponding to the development in each one of the irregular moults, as well as their duration (D) in specimens of Mus spretus born in laboratory and dyed later. $\mathrm{N}=$ number of animal and each one of moults analyzed. $\mathrm{B}=$ birth date.

\begin{tabular}{|c|c|c|c|c|}
\hline $\mathrm{N}$ & B & Dates & Age & D \\
\hline $\begin{array}{l}1 \mathrm{a} \\
1 \mathrm{~b} \\
1 \mathrm{c}\end{array}$ & 20.07 .85 & $\begin{array}{l}11.10 .85-17.10 .85 \\
25.11 .85-02.12 .85 \\
22.01 .86-04.02 .86\end{array}$ & $\begin{array}{r}81-87 \\
126-133 \\
184-197\end{array}$ & $\begin{array}{r}6 \\
7 \\
13\end{array}$ \\
\hline $\begin{array}{l}2 \mathrm{a} \\
2 \mathrm{~b} \\
2 \mathrm{c}\end{array}$ & 20.07 .85 & $\begin{array}{l}12.12 .85-28.12 .85 \\
20.01 .86-28.01 .86 \\
18.03 .86-31.03 .86\end{array}$ & $\begin{array}{l}143-159 \\
182-190 \\
239-252\end{array}$ & $\begin{array}{r}16 \\
8 \\
13\end{array}$ \\
\hline $\begin{array}{l}3 \mathrm{a} \\
3 \mathrm{~b} \\
3 \mathrm{c}\end{array}$ & 25.08 .85 & $\begin{array}{l}17.02 .85-03.03 .85 \\
21.03 .86-17.04 .86 \\
09.05 .86-06.06 .86\end{array}$ & $\begin{array}{l}175-189 \\
210-235 \\
267-285\end{array}$ & $\begin{array}{l}14 \\
25 \\
18\end{array}$ \\
\hline $\begin{array}{l}4 \mathrm{a} \\
4 \mathrm{~b} \\
4 \mathrm{c} \\
4 \mathrm{~d}\end{array}$ & 20.07 .85 & $\begin{array}{l}12.12 .85-28.12 .85 \\
13.04 .86-24.04 .86 \\
12.05 .86-22.05 .86 \\
07.06 .86-18.06 .86\end{array}$ & $\begin{array}{l}143-159 \\
265-274 \\
294-304 \\
320-331\end{array}$ & $\begin{array}{r}16 \\
9 \\
10 \\
11\end{array}$ \\
\hline
\end{tabular}



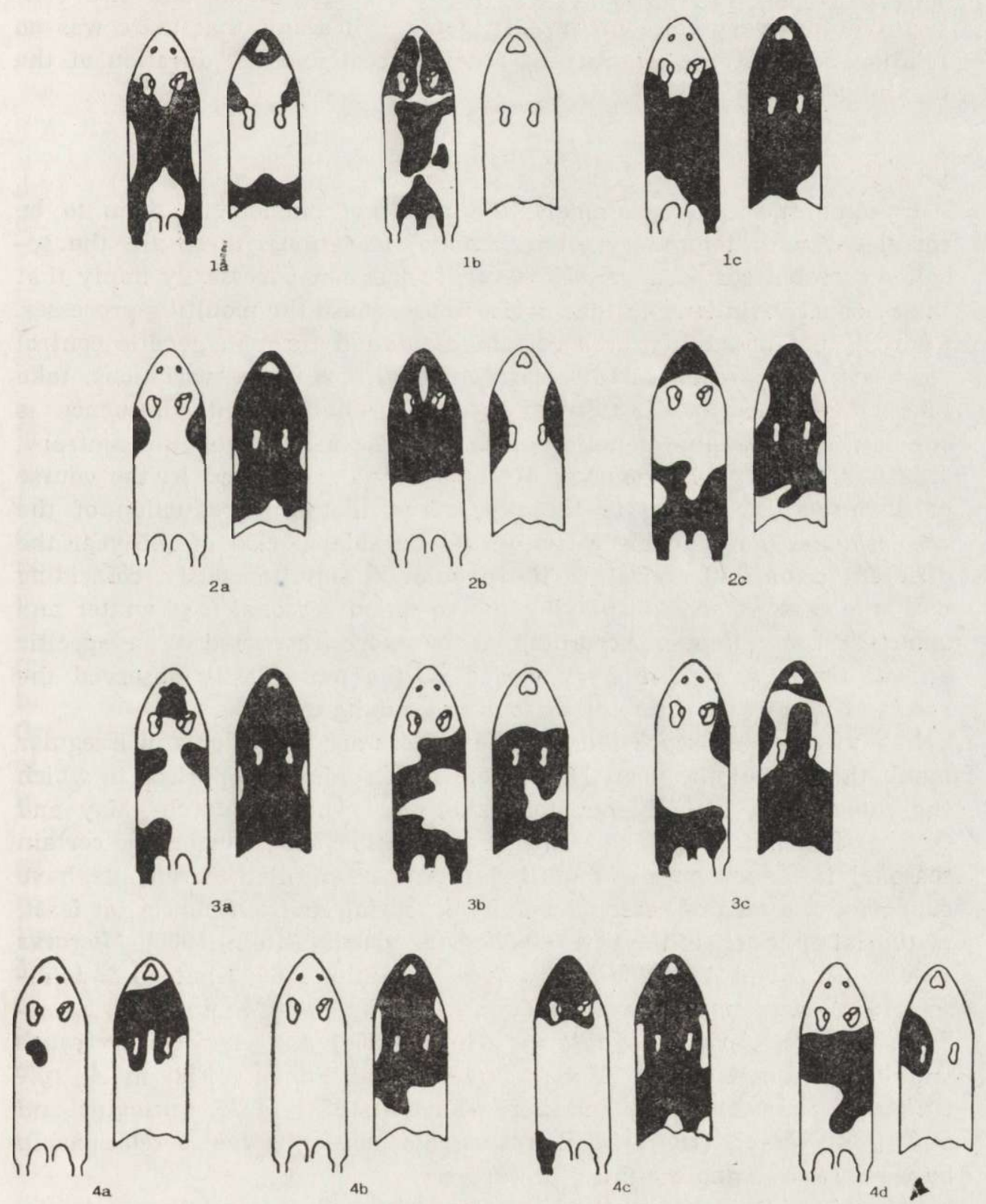

Fig. 5. Areas of coat moulting in each one of the irregular moults studied on dyeding animals in captivity. See also Table 2. 
times in different places from the previously affected ones, so it was difficult to distinguish at first between a single moult and two consecutive ones very close in time. In general, it seems that there was no relation between the quantity of renewed coat and the duration of the moulting process.

\section{DISCUSSION}

In some species of mammals, the moulting phenomena seem to be correlated with temporary environmental variations; these are the socalled seasonal coat changes. However, it does not necessarily imply that the seasonal variations, in their wider sense, cause the moulting processes. There is the possibility of a certain regulation through genetic control related to age. When moults, correlated with seasonal variations, take place, it remains unclear to what extent the environmental influence is supplanting a possible genetic determinism or whether on the contrary, it is a secondary phenomenon of superposition, acquired in the course of evolution. According to these premises, if the reproduction of the species takes place during a limited (favourable) period of the year the different coats will appear in the population simultaneously, coinciding with the seasons, thus displaying the so-called seasonal (e.g. winter and summer) coat change. Accordingly, the more restricted to a specific annual time the reproductory period is, the more easily observed the result of the superposition of seasons and moults must be.

In Mus spretus, as previously stated, there are individuals in irregular moult throughout the year. Nevertheless, there are two periods in which the rates are a little higher than the yearly mean: March-May and October-December (Fig. 2). This concentration may suggest a certain seasonal influence on the moulting processes. Similar increments have supported the idea of seasonal moults, in spring and autumn or, at least, in the latter. Such is the case of Microtus arvalis (Stein, 1960), Microtus oeconomus (Stein, 1960), Microtus agrestis (Stein, 1960; Khateeb \& Johnson, 1971), Apodemus sylvaticus (Von Lehmann, 1958; Stein, 1960; SaintGirons, 1967), Apodemus agrarius (Stein, 1960) and Arvicola terrestris (Buhlow, 1970). However Fullagar (1967) and Röben (1969) in A. sylvaticus, Dynowski (1963) and López-Fuster (1978) in M. musculus and Sans-Coma et al. (1987) in $R$. rattus, did not observe a relationship between seasons and moulting processes.

There is an increase in the rate of moulting in a paralell way to the increase of the number of animals in moult during the months of October-December. All these factors seem to show a certain seasonal influence on the control of the irregular coat changes, but the topographic divergences, the lack of a consistent time pattern of moulting among 
the specimens dyed in the laboratory as well as the existence of a high percentage of animals that do not moult within the above mentioned period or those that moult out of this time period, and the existence of wide areas of coat with no alterations, recommend the rejection of the idea of a seasonal moult in its stricter sense, in which case winter and summer coats with different appearance and composition should be evident. It must also be taken into account that the moulting rates do not increase throughout the months of March-May, while the number of moulting animals increases.

Consequently, the environmental conditions are not the sole determining factor which cause the irregular coat changes, although, beyond all doubt, they somehow affect the characteristics of the coat that the animals develop (see Haitlinger, 1968; Vargas et al. in press).

From the acquisition of the third coat, irregularity is the dominant feature in the topographic distribution of the moulting areas. Nevertheless, as Fullagar (1967) shows in A. sylvaticus, symmetrical pigmentation patterns occasionally appear that may be confused with patterns of regular moulting. The individual nature of each irregular moult does not allow us to do topographic or time predictions about the pattern of coat change that any animal may undergo. Probabilistic trends can be observed just in a population level. The final result of moult is symmetrical, that is, not all the body areas moult with equal frequency or intensity, but each one of them does it equitably over its whole surface (left and right). This symmetrical pattern remains throughout the life of the animals although a slight insignificant distortion can be observed in old age.

The diffused moult was described in Eliomys quercinus quercinus (Kahmann \& Tiefenbacher, 1970), and it has been observed in other rodents species: M. arvalis (Gosálbez, 1976), A. sylvaticus (Saint-Girons, 1967; Sans-Coma et al., in press), R. rattus (Sans-Coma et al., 1987) and Mus spretus (España et al., 1985). Due to its characteristics, this type of irregular moult may not be clearly seen through the coat dyeings, so it is even more difficult to specify its real incidence throughout the life of the animals. Some authors have pointed out the possibility of this pattern of coat changes representing the last phases of partially or totaly irregular moultings (Gosálbez, 1976). It may in fact be replacements of hair locks which have shed because of mechanical disturbance. In any case, the cause and significance of the diffused moults, in the sense in which they have been considered here, are unknown for the moment. It is important to define precisely this last phenomenon, since there are authors who include any observable irregular coat changes under the category of diffused moult (see e.g. Kryltzov, 1964). 
Acknowledgements: The authors wish to thank Dr. Miguel A. Alonso for his review of the English translation and Dr. Andrzej L. Ruprecht from Mammals Research Institute Polish Academy of Sciences for his kindly suggestions. This work was financed by DGICYT, PB86-0581-C03-00.

\section{REFERENCES}

1. Backer K., 1952: Haarwechselstudien an Wanderratten (Rattus norvegicus). Biol. Zentrablatt, 71: 626-640.

2. Buhlow E., 1970: Untersuchungen über den Haarwechsel bei Schermäusen, Arvicola terrestris (L., 1758). Zool. Anz., 184: 17-31.

3. Dynowski J., 1963: Morphological variability in the Bialowieża population of Mus musculus Linnaeus, 1758. Acta theriol., 7: 51-66.

4. Dry F. 1926: The coat of the mouse (Mus musculus). J. Genetics, 16: 287-340.

5. España M., Palomo L. J., Zamorano E. \& Sans-Coma V., 1985: Úber Haarwechsel und Haarkleid von Mus spretus Lataste, 1883 aus Südspanien. Spixiana, 8 (1): 1-16.

6. Fullagar P. J., 1967: Moult in field mice and the variation in the chest markings of Apodemus sylvaticus (Linné, 1758) and Apodemus flavicollis (Melchior, 1854). Säugetierkdl. Mitt., 15: 138-149.

7. Gosálbez J., 1976: Sobre el cambio de pelaje en Microtus arvalis Pallas, 1778, de los Pirineos catalanes. P. Dept. Zool., 1: 35-40.

8. Johnson E., 1958: Quantitative studies of hair growth in the albino rat. I. Normal males and females. J. Endocrin., 16: 337-350.

9. Haitlinger R., 1968: Seasonal variation of pelage in representatives of the genus Apodemus Kaup, 1829, found in Poland. Zool. Pol., 18 (3): 329-345.

10. Kahmann H. \& Tiefenbacher L., 1970: Uber Haarwechsel und Haarkleid des Gartenschäfers Eliomys quercinus Linnaeus, 1776. Z. Säugetierk., 35: 89-103.

11. Khateeb A. A. \& Johson E., 1971: Seasonal changes of pelage in the vole (Microtus agrestis). I. Correlation with changes in endocrine glands. Gen. Com. Endocr., 16: 217-228.

12. Kryltzov A. I., 1964: Moult topography of Microtinae, other rodents and lagomorphs. Z. Säugetierk., 29: 1-17.

13. Lehmann E von, 1958: Zum Haarwechsel deutscher Kleinsäuger. Bonn. zool. Beitr., 9: 10-22.

14. López-Fuster M. J., 1978: Sobre Mus musculus Linnaeus, 1758 en el Nordeste ibérico. Tesis de Licenciatura. Universidad de Barcelona.

15. Röben P., 1969: Ein für europäische Kleinsäuger neues Haarwechselschema. Zur Gattung Apodemus im Rhein-Neckergebiet. Säugetierkdl. Mitt., 17: 31-42.

16. Saint-Girons M. C., 1967: Etude du genre Apodemus Kaup, 1829 en France (suite et fin). Mammalia, 31: 55-100.

17. Sans-Coma V., Rosado L. M. \& Gosálbez J., Un estudio de la morfometría y del comienzo de la actividad reproductora de Apodemus sylvaticus (L., 1758) en la Península Ibérica basado en la consideración de los pelajes y mudas como indicadores de la edad. [In: "Mamíferos y Helmintos - Un homenaje al Prof. Dr. Dr. Hermann Kahmann en su 80. aniversario". Ed. M. Bach.] Barcelona (in press).

18. Sans-Coma V., Zamorano E., Vargas J. M. \& Antúnez A., 1987: Zum Haarwechsel freilebender Hausratten Rattus rattus (1., 1758) in Südspanien. Zool. Abh. Dresden, 42 (2): 125-136.

19. Schaible R. H., 1969: Clonal distribution of melanocytes in pieboldspotted and variegates mice. J. Exp. Zool., 172: 181-199. 
20. Schmidt E., 1970: Untersuchungen über Fortpflanzung, postnatale Entwicklung und Kreuzbarkeit von Waldmaus (Apodemus sylvaticus Linnè, 1758) und Gelbhalsmaus (Apodemus flavicollis Melchior, 1834) unter Laboratoriumsbedingungen. Doctoral Thesis. University of München.

21. Sealander J. A., 1951: Survival of Peromyscus in relation to environmental temperature and acclimation at high and low temperatures. Am. Midl. Nat. 46: $257-309$.

22. Stein G. H. W., 1960: Zum Haarwechsel der Feldmaus, Microtus arvalis (Pallas, 1778) und weiterer Muroidea. Acta theriol., 4: 27-43.

23. Vargas J. M., Palomo L. J. \& Sans-Coma V., Estudio cuantitativo de los pelajos del ratón moruno, Mus spretus Lataste, 1883. [In: "Mamiferos y Helmintos - Un homenaje al Prof. Dr. Dr. Hermann Kahmann en su 80. aniversario. Ed. M. Bach.] Barcelona, (in press).

Received 6 July 1987, Accepted 7 September 1987

L. Javier PALOMO i J. Mario VARGAS

O NIEREGULARNEJ LINCE U MUS SPRETUS LATASTE, 1883

\section{Streszczenie}

Na materiale 1516 osobników Mus spretus złowionych od marca 1982 do lutego 1986 zanalizowano przebieg nieregularnej linki. Osobniki liniejące występowały w ciągu całego roku kalendarzowego, nieznacznie więcej niż wartości średnie w okresach od marca do maja i od października do grudnia (Ryc. 2). W tych ostatnich miesiącach także tempo linienia było nieco szybsze (Tabela 1). Nie stwiepdzono jednak wyraźnej sezonowości w przebiegu tego zjawiska. 